\title{
Glioblastome Multiforme 'de Güncel Durum ve Uzun Yaşam
}

Current Situation and Long Life in Glioblastome Multiforme

${ }^{1}$ Faruk Altınel, ${ }^{2}$ Nur Altınörs

${ }^{1}$ Başkent Üniversitesi, İzmir Zübeyde Hanım Hastanesi, Nöroşirurji Kliniği, İzmir, Türkiye

${ }^{2}$ Acıbadem Ankara Hastanesi Nöroşirurji Kliniği, Ankara, Türkiye

\section{Correspondence:}

Faruk ALTINEL

Başkent Üniversitesi, İzmir Zübeyde Hanım Hastanesi, Nöroşirurji Kliniği, İzmir, Türkiye

e-mail: farukaltinel@gmail.com

\section{Özet}

Glioblastome Multiforme (GBM) özellikle orta ve ileri yaş grubunda sık görülen, en kötü huylu primer beyin tümörüdür. Cerrahi rezeksiyon, radyoterapi ve kemoterapiyi içeren üçlü tedaviye rağmen sağ kalım süresi ortalama bir yıl civarındadır. Bu tanıyı almış, üç yıl veya daha uzun süre yaşamda kalmış hastaların uzun yaşadığı düşünülür. GBM hastalarının çok düşük bir yüzdesi bu gruba girer. Uzun yaşadığı gözlenen GBM'li olgularda histopatolojik tanının tekrar gözden geçirilmesi gerekir. Uzun yaşamla ilişkil faktörler kesin olarak bilinmemektedir. Genç yaş, Karnofsky skoru yüksekliği ve Metil Guanin MetilTransferaz(MGMT) metilasyonunun GBM'li hastalarda daha iyi bir prognoz ve daha uzun sağ kalımla ilişkili olduğu öne sürülmüştür.

Anahtar kelimeler: Beyin tümörü; Glioblastome multiforme; Kemoterapi; Radyoterapi;Cerrahi

\section{Abstract}

Glioblastome multiforme (GBM) is the most frequent and most malignant primary brain tumor seen especially in the middle and elderly age group. Survival, despite therapy including surgical extirpation, postoperative radiotherapy and chemotherapy is one year on average. Survival of three years or more is considered long survival. A very low percentage of GBM patients fall into this category. In such cases histopathologic diagnosis has to be reconfirmed. Factors associated with this condition are unknown. Young age, preoperative high Karnofsky score and methyl guanine methyl transferase (MGMT) methylation have been proposed to be associated with better prognosis and longer survival in GBM patients.

Keywords: Brain tumor; Glioblastome multiforme; Chemotherapy; Radiotherapy; Surgery 


\section{Giriş}

Diffüz infiltratif gliomlar meningiomlardan sonra en sik görülen primer santral sinir sistemi tümörleridir. Tüm santral sinir sistemi(SSS) tümörlerinin \% 22'sini oluşturur. Ek olarak GBM ise, en s1k görülen malign santral sinir sistemi tümörleridir ve SSS tümörlerinin \% 14,6'sın1, malign santral sinir sistemi tümörlerinin \% 48,3'ünü oluşturur(1). Ayrıca GBM, tüm kanserlerin \%1,4'ün da, kansere bağl1 ölümlerin $\% \quad 2,9$ 'unda rastlanır(2). Tedavi edilmeyen GBM hastalarında, ortalama sağkalım süresi sadece 3 ay olup agresif bir neoplazmdir(3). Tedaviye rağmen tanıdan sonra ortalama sağ kalım süresi genellikle 12 ila 18 ay arasındadır. Beş yıllık yaşam süresi tanıdaki yaş ve cinsiyete göre değişmekle birlikte ortalama $\% 6,8^{\prime}$ dir. On yıldan fazla yaşayanlar $\%$ l'den daha azdir(4). GBM tedavisinde cerrahi önemli bir seçenektir. Cerrahi, klinik tanının histolojik olarak doğrulanmasını sağlar ve ayrıca tam rezeksiyonla sağkalım süresini artırır, dekompresif ve sitoredüktif etkiye sahiptir. Rezektif cerrahinin ana kontrendikasyonları, kötü performans durumu (70'in altında Karnofsky), ileri yaş ve önemli yerleşim yeridir(3). Rekürens, hastalığın seyri boyunca kaçınılmaz bir sonuç olup, rekürens görüldükten sonra ortalama sağ kalım süresi 5-7 ay arasindadır.

GBM,frontal ( $\% 43$ ), temporal ( $\% 28$ ), parietal ( $\% 25)$ ve oksipital ( $\% 4$ ) loblarda olmak üzere daha çok supratentoriyal kompartmanda görülür. Serebellumda ve çocuklarda görülmesi seyrektir. Erkeklerde kadınlara göre 1,6 kat, beyaz 1rkta Afrikalı ve Afrika kökenli Amerikalılarda iki kat fazla görülür. Amerika Birleşik Devletlerinde görülme oranı $3,19 / \quad 100,000$ nüfus ve ortalama görülme yaşı 64 olarak saptanmıştır (3). $\mathrm{Bu}$ makalede, GBM'li olgularda uzun yaşamla ilgili literatur incelemesi ve GBM serimizde üç yılı aşkın yaşayan altı olgudan üçünde yapılan genetik çalışma sonuçları sunuldu.

\section{Tartışma}

Glioblastomların oluşum ve yayılmasında; astrositlerin, nöroglial kök veya progenitor hücreler, oligodendrosit prekürsör hücreler ve glioblastoma kök hücrelerin rol oynadığı düşünülmekle beraber kesinlik kazanmamıştır. $\mathrm{Bu}$ tümörler moleküler heterojenite gösterirler.

Bilinen risk faktörleri GBM tanısı almış olguların çok düşük yüzdesinde geçerlidir. Baş ve boyuna iyonize radyasyon risk faktörü olarak belirlenmiştir. Cep telefonu kullanımının beyin tümörü oluşumuna yol açma potansiyeli ile ilgili yoğun araştırmalar yapılmış, fakat kanıtlanabilen bir ilişki saptanmamıştır(5). Glioblastomalı hastaların büyük çoğunluğunda aile kanser öyküsü yoktur. Tüm gliomların \% 5'i ailevidir.

Malign gelişme ile ilgili olarak iki tür glioblastoma vardır. De novo oluşanlar, primer tip GBM dir. yetişkinlerde görülen diffüz infiltratif gliomların en kötü prognoz gösteren tipidir. $\mathrm{Bu}$ tümörler ileri yaşlı ve beyaz ırkta daha sık görülür, klinik öykü kısa sürelidir ve yaşam süresi sınırlıdır. Düşük grade'li gliomların evrilmesiyle oluşanlar ise sekonder tip GBM olarak isimlendirilir. sekonder gliomlar daha genç yetişkinlerde görülür. İki tip arasında cinsiyet farklılığı, hormonal değişiklikler ve genetik özellikler ile açıklanmaktadır.

Dünya Sağlık Örgütü ( DSÖ), 2016 yılında Santral Sinir Sistemi (SSS) tümörleri sınıflamasını güncellemiștir. Güncellemede en önemli nokta; mikroskopik bulgulara dayanarak yapılan alışılmış patolojik değerlendirme ve tanılara belirli moleküler özelliklerin eklenmesi olmuştur. Tedavi şemalarının belirlenmesinde de; histogenetik siniflandirma ve derecelendirme sisteminin prognozla kabaca ilişkili olmasının yarar sağladığı, uzun süre uygulama alanı bulduğu belirtilmiştir. Ancak son yıllarda genetik ve epigenetik konularındaki buluşlar, histogenetik sinıflamanın sorgulanmasına yol açmıştır. Bu sorgulamanın belli başlı üç ana nedeni vardır. Öncelikle bir tümörün içinde değişik farklılaşmaların birlikte olması mümkündür, ayrıca DSÖ sinıflamasında; tümör derecelendirmesi ile prognoz arasındaki ilişki, ana moleküler belirleyicilerle prognoz 
arasındaki ilişkiye kıyasla daha zayıfdır. Son olarak moleküler testler, mikroskopik değerlendirmeye oranla çok daha objektifdir ve tekrarlayabilme özelliği vardır.

Klasik hematoksilen-eozin boyası ile elde edilen histolojik sonuç tümör için ilk tabakalandırmayı oluşturmaktadır. Tanıya göre tümörün ait olduğu ana grup belirlenmektedir. Daha sonra moleküler değerlendirme ile alınan sonuçlar tanıya eklenir ve böylece tümörün alt tabakalandırması yapılmış olur. DSÖ,2016 yılı SSS tümörleri güncellemesinde, fenotipik ve genotipik sinıflandırmaların birlikte kullanılmasını öngörmektedir. Bir başka yeni kavram,tabloları olabilecek en dar şekliyle tanımlamak amaciyla NOS ( not otherwise specified) kavramının öne sürülmüş olmasıdır. Buna göre NOS'un üç durumda kullanılması önerilmiştir: a) genetik testlerin yapılmadığ 1 durumlar, b) genetik test sonuçlarının histolojik bulgularla uyumlu genetik değişiklikler göstermemesi hali, c) yetersiz doku örneği veya doku artefaktına bağlı olarak tümörün yapısı veya sitolojik özellikleri hakkında şüphe varlığı.

Glioblastom, malign infiltratif bir astrositom olup tanı açısından nekroz ve/veya mikrovasküler proliferasyonun değerlendirilmesi esastır. Histolojik özellikleri açısından glioblastoma çok değişkenlik göstermektedir. Tanısal ve prognostik öneme sahip paternler, psödopalizatlaşma gösteren nekroz, konfluan nekroz, mikrovasküler proliferasyon, intravasküler tromboz, değişik yönlere farklılaşma gösteren tümör hücrelerinin varlığıdır. Astrositik orijinli olduğu için glioblastomların büyük çoğunluğu GFAP(Glial Fibriler Asidik Protein ) eksprese eder. Başta CAM 5.2 olmak üzere keratin boyaları metastatik karsinom, glioblastoma ayrımında GFAP ile birlikte kullanılır. Glioblastom, malign melanom ayrımında S100 proteini ile glioblastomda da immünreaksiyon görüleceği için öncelikle HMB45(Human Melanoma Black),MITF(Microphthalmia Transcription Factor), Melan A ve tirozinaz gibi melanositik belirteçlerin değerlendirilmesi önemlidir(6).
Gliomagenesiste ilk görülen gen değişmeleri, izositrat dehidrojenaz (IDH) mutasyonudur. Daha sonra TP53 ve ATRX mutasyonları izler. IDH mutasyonu, beyin tümörleri için daha iyi tanımlanmış bir genetik değişimdir ve yeni DSÖ sinıflandırmasına entegre edilmiştir. $\mathrm{Bu}$ yenilikler kapsamında ; glioblastomalar, IDH wild tip (IDH wt) ve IDH mutant tip(IDH 1,2) olarak iki ana gruba ayrılmıştır(7). IDH 1 ve IDH 2 gen değişimleri ve kromozom 1P , 19q kod kayb1 varlığına veya yokluğuna bağlı olarak, yetişkinlerde primer glioblastom IDH wt olarak tanımlanır. Yine sekonder glioblastomlar da IDH gen değişimi ve 1P / 19q kod kaybı olabilir ya da olmayabilir. IDH 1 de olan gen değişimleri daha çok 132 kodlu gende olur. Vakaların \% 90 da gen değişimi $\mathrm{R} 132 \mathrm{H}$ genindedir. IDH 2 gen değişimleri daha az siklıkla 172 kodlu gende olur, en s1k R172K da görülür (4).

IDH 1 ve 2 mutasyonları genetik ve klinik olarak ayrı bir glioma tipini oluşturur. Bu tür tümörün görüldüğü hastalar histopatolojiden bağımsız olarak daha iyi prognoz gösterir, kemoterapi ve radyoterapiye daha olumlu yanit verir. Ancak IDH mutasyonunun tümör supresor fonksiyonunun moleküler temeli aydınlanmamıştır. Bunun aksine IDH wt, GBM hücrelerinin metabolik adaptasyonunu kolaylaştırarak agresif büyümeye yol açar. Böylece wt ve mutant IDH $1 / 2$ arasındaki fonksiyonel dengenin klinik gidiş, kemoterapi ve radyoterapiye duyarlılığ sürülmüştür(8). Gliom oluşumunda, MGMT metilasyonu testinin yapılamadığ 1 durumlarda IDH mutasyonuna bakılabilir

GBM' e ait spesifik klinik semptom yoktur. Yeni ortaya çıkan epileptik nöbetler, ilerleyici baş ağrısı,

mental durum değişiklikleri, fokal nörolojik semptomlar, artmış intrakranial basınç belirtileri başlica şikayetlerdir. Radyolojik tanıda öncelikli seçenek, kontrastlı manyetik rezonans (MR)'dır. Bu tümörler, nekrotik alanlar içeren, kontrast madde tutan, çevresinde ödem olan görüntü verirler. Ayırıcı tanıda düşük grade'li gliomlar, metastazlar ve bazen lenfoma düşünülmelidir. Apse ve 
demyelinizan lezyonlar da ayırıcı tanıda akılda tutulmalıdır.

Dinamik kontrastlı perfüzyon ağırlıklı MR kesitler(DSC-MRI)de serebral kan akımını ölçmek mümkündür. Serebral kan akımı, mikrodamar dansitesi ve alanı ile ilişkilidir(9).Tümörün indüklediğgi anjiyogenezise bağlı oluşan mikrovasküler proliferasyon GBM için önemli bir göstergedir.(10). Serebral kan akımı GBM'in diğer tümör tiplerinden ve histolojik gradelerinden ayırt edilmesine de katkı sağlar(11).

MR spektroskopi, tümör içinde metabolitlere ait yoğunluk değişikliklerini belirler. Glioblastomlarda tipik olarak artan hücre proliferasyonuna bağlı olarak oldukça yüksek kolin değerleri ve nöron kaybı nedeniyle azalana $\mathrm{N}$-asetil aspartat değerleri gözlenir(12). Ancak benzer değişikliklere diğer neoplastik patolojilerde ve inflamatuar hastalıklarda da rastlanır(13).Beynin özellikli lokalizasyonlarında görülen tümörlerde fonksiyonel MR cerrahi planlama ve güvenlik sınırları içinde maksimum rezeksiyonun yapılabilmesi için yarar sağlar.

Pozitron emisyon tomografi (PET), tümör biyolojisi ve yaygınlığı hakkında fikir vermesinin yanısıra ayırıcı tanıda, radyoterapi planlamasında, tedavi sonrası izlemde tümör ilerlemesi veya yalanc1 tümör ilerlemesi hakkında da bilgi sağlar(14).

GBM'in genetik taranmasında ortak kayıp bölgeleri olarak $1 \mathrm{p}, 6 \mathrm{q}, 9 \mathrm{p}, 10 \mathrm{p}, 10 \mathrm{q}, 13 \mathrm{q}$, $14 \mathrm{q}, \quad 15 \mathrm{q}, \quad 17 \mathrm{p}, \quad 18 \mathrm{q}, 19 \mathrm{q}, \quad 22 \mathrm{q}$ ve $\mathrm{Y}$ saptanmıştır. $\mathrm{Bu}$ genetik kayıpların çoğu spesifik tümör supresor gen kaybını temsil eder, bu da direkt olarak gliomagenez üzerine etkilidir. GBM'li hastalarda \% 60-80 oranında görüldüğü için en sik rastlanan genetik değişiklik $10 . \quad$ kromozomdaki heterozigotluğun kaybıdır. GBM'de genomik düzeyde genetik değişikliklere bağlı olarak gen ifadesi kazançları gösterilmiştir. $\mathrm{Bu}$ şekildeki artmış gen ifadesi, gen ifadesi kayıplarına göre çok seyrek görülür. En sık gözlemlenen olay 7. kromozomdaki EGFR geninin amplifikasyonudur(15).
Günümüzde GBM'in standart tedavisi güvenlik sınırları içinde maksimum cerrahi rezeksiyon sağlandıktan sonra radyoterapi ve eş zamanlı kemoterapidir. 5- aminolevulinik asitten türetilen tümör floresans1, kontrast tutan tümörün, en geniş rezeksiyonunu mümkün k1larak GBM'li hastalarda ilerlemesiz sağkalımın artmasına yol açtı(3). Radyoterapinin en sik kullanılan uygulaması günlük 2 Gy olmak üzere 30 fraksiyon halinde toplam 60 Gy'dir. Radyoterapi planlamas1 ameliyat sonrası çok erken dönemde çekilen MR'da saptanan hedefler gözetilerek yapılmaktadır(16). Yaşlı olgularda üç haftada tamamlanan günlük 2.6 Gy'nin 15 fraksiyon halinde toplam 40 Gy olarak verilen hipofraksiyon şeklindeki tedavinin standart protokol ile eşdeğer etkiye sahip olduğuna ait kanıt bulunmaktadır(17).

Kemoterapötik ajan olarak Temezolamid(TMZ), $75 \mathrm{mg} / \mathrm{m} 2 /$ gün x 6 hafta olarak başlanır. İdame dozu 150-200 $\mathrm{mg} / \mathrm{m} 2 /$ gün x 5 gün olmak üzere 28 günlük alt1 siklus şeklindedir(18). MGMT metile olmayan tümörlerde temezolamid etkisi minimaldir, dolayısıyla bu özelliği gösteren seçilmiş olgularda temezolamid verilmeyebilir(19). Radyoterapi ve TMZ kemoterapisinin kombinasyonu, birincil rezeksiyonu takiben sağkalımı uzattığı gösterilen en etkili adjuvan tedavidir. Radyoterapi ve ardından TMZ, tek başına radyoterapi ile karşılaştırıldığında önemli ölçüde uzun süreli sağkalım sağlar(3).

Üçlü tedaviye rağmen günümüzde GBM'in prognozunu anlamlı şekilde iyileştiren, kür sağlayan sonuçlar elde edilememiştir. $\mathrm{Bu}$ durum tamamen yeni tedavi modalitelerinin araştırılmasını gerekli kılmıştır. Bu seçenekler hedeflenmiş moleküler tedavi, immunoterapi ve viral tedavidir. GBM tedavisinde karşılaşılan önemli bir sorun ileri derecede intratümöral ve tümörler arası heterojenite göstermesidir. Ayn1 tümörün farklı bölgelerinde değişik genetik kompozisyona sahip hücreler, transkripsiyonel alt gruplar ve proliferasyon kinetikleri görülebilir. GBM'li hastada ilk spesimenle rekürens görüldüğünde alınan spesimen kıyaslandığında EGFRvIII (epidermal growth factor receptor variant III) mutasyonu gibi belirli genetik değişikliklerle 
geçici heterojenite görülebileceği bildirilmiştir(20).

Krex ve ark. 55 olguluk uzun yaşamlı GBM olgularını değişik parametreler kullanarak incelemişlerdir. Yapılan moleküler analizde \%74 olguda MGMT hipermetilasyonu, \% 29 olguda TP 53 mutasyonu ve \% 26 olguda EGFR amplifikasyonu saptamışlardır. Sadece $\% 6$ tümörde $1 p$ ve $19 q$ delesyonu kombinasyonu görülmüştür Glioblastomdaki TP53 mutasyonlarının tanıya olan etkinliği EGFR amplifikasyonuna benzer şekilde, tam aydınlatılamıştır.Bazı çalışmalarda TP53 mutant tümörlü hastaların daha iyi prognozu bildirilmiştir (21).EGFR amplifikasyonu tüm glioblastomlarda \%30-40 olup genellikle primer glioblastoma sinırlidır. EGFR amplifikasyonu olan olguların yaklaşı $\% 50$ 'sinde tirozin kinaz aktivitesine neden olan EGFRvIII rearanjmanı ile sonuçlanır. Liu ve ark. EGFR amplifikasyonunun veya EGFRvIII transcript varlığının klasik yöntemlerle tedavi gören GBM'li hastalarda prognozu etkilemediği sonucuna varmışlardır. Buna karşın nadir de olsa astrositik astrositomlarda EGFR aberrasyonlarının daha kısa sağ kalımla ilişkili olabileceğini öngörmüşlerdir(22).

Hegi ve ark. intratümöral MGMT (06metilguanin-DNA- metiltransferaz) sessizliği ile să kalım arasındaki olası ilişkiyi araştırmışlardır. Çalışmaya randomize olarak sadece radyoterapi alan GBM hastaları ile radyoterapi ile birlikte temozolomid alan hastalar alınmıştır. Sonuçta metile MGMT promoter gösteren olguların temozolomid'den yarar gördüğü gözlenmiş, aynı etki metile MGMT promoter göstermeyen olgularda görülmemiştir. Böylece MGMT DNA onarım geninin promoter metilasyonu ile epigenetik susturulmasının alkile edici ajan tedavisi alan GBM hastalarda sağ kalımı uzattığı sonucuna varılmıştır. MGMT epigenetik sessizleşmesine $\quad \% \quad 20-40 \quad$ oranında rastlanır(23).

Nörodejeneratif hastalıklarla ilişkili olan MAPT ( Microtubule- Associated Protein) ve TAU geni epigenetik olarak insan gliomlarında wt ve mutant IDH 1/2 arasındaki denge tarafindan kontrol edilmektedir.
Gargini ve ark. IDH 1/2 mutant tümörlerde TAU genini yüksek bulmuşlardır. Tümörün ilerlemesiyle TAU geni azalmıştır. EGFR ( epidermal growth factor receptor) mutasyonu olan tümörlerde MAPT'in hemen hemen hiç olmadı $\breve{g}_{1}$, TAU'nun aşırı ifadesinin mikrotübül stabilizasyonu sağlayarak EGFR'1 bloke ettiği gösterilmiştir. Çalışmanın sonucu gliomlarda TAU'nun EGFR sinyalinin önemli bir inhibitörü olduğunu ortaya koymuştur. Bazı kanserlerde yazarlar, TAU proteininin anjiyogenezisi engellediği, normal damarlaşmaya yol açtığı, gliomun agresifliğini azalttığı ve kemoterapiye duyarlılığını arttırdığını göstermişlerdir(24).

Mikrotübül fonksiyonunu etkileyen ilaçlar, hücrelerin mitozdan korunmasını sağlayabilir ve hücre döngüsü durmasina veya apoptoza neden olabilir. Stabilize ve inhibe edici bir çok mikrotübül hedefleyen ajan kanser tedavisinde kullanılmıştır. Bazı kanserlerde mikrotübül fonksiyonu ile zıtlaşan ilaçların EGFR inaktivasyonu ile ilişkili olduğu görülmüştür(25).

GBM serimizde üç yılı aşkın yaşayan altı olgudan üçünde genetik çalışma yapılmıştır. Üç yıldan fazla yaşam sürdükleri için 1. ve 3 . olguların tekrarlayan ameliyatlarında GBM tanısı almışlardır. İlk ameliyat preparatları yeniden değerlendirilmiş ve GBM tanısı sabit kalmıştır. İkinci olgu bir kez ameliyat edildiği için patolojik tanısı yeniden değerlendirilmiş ve tanı GBM olarak kalmıştır. Bu olguların genetik çalışma sonuçları şu şekildedir:

\section{Olgu 1}

45 yaşında erkek hasta. Üç kez tümör için, bir kez BOS kaçağ 1 tamiri için duraplasti ameliyatı yapıldı. Radyoterapi ve kemoterapi aldı. İlk cerrahi sonrası 65 aydır hayatta.

aCGH analizi Xp22.33-21.1, 1p13.1-p36.32, 3q13.33-q26.31, 6q13 - q27, 8p23.3 p11.21,13q11 - q31, 17 p13.3 - p12,18 p11.32-p11.21, 19q12- q13.43, 20p13-p11.21, 22q12.1-q13.33 kromozomlarında kısmi kopya kayıları ve 1q, 4p, 9p, 19p kromozomlarında kısmi kopya kazanımları saptand1.2,5,11,12 ve 17 'ci kromozomlarda tam kromozom kazanımı görülürken 10,15 ve 
16'c1 kromozomların monosomik olduğu anlaşıld.

\section{Olgu 2}

69 yaşında kadın hasta. Sağ oksipital yerleşimli GBM. Cerrahi sonrası radyoterapi ve yurtdışında kemoterapi aldı. Ameliyatdan 78 ay sonra kaybedildi

aCGH analizi 1p36.11-p35.2, 2p23.3, 3q26.33-q27.3, 5q31.2-q31.3,8q24.3,9q31.3q32, $\quad 12 \quad$ q24.31, $22 \mathrm{q} 11.21-\mathrm{q} 11.22$ kromozomlarında kısmi kopya kayıpları ve 1p21.1 - p13.3,2p12 - p11.2, 7p12.1 -

p11.2 kromozomlarında k1smi kopya kazanımları gösterdi. Tüm kromozom kaybı veya kazancı gözlenmedi.

\section{Olgu 3}

40 yaşında erkek hasta, temporo-oksipital yerleşimli GBM. İki kez ameliyat edildi. Radyoterapi ve kemoterapi ald1.111 aydır hayatta.

aCGH analizi 3q11.1q13.31, 9p24.3p13.1, 15q14q15.1, 6p12.1p11.1, 16q23.2q24.3, 18p11.32p11.21, $\quad$ 19q13.31q13.41 kromozomlarında kısmi kopya kayıpları ve 6p21.1p12.3, $\quad$ 19p12, $\quad 19 q 11 \mathrm{q} 13.12$

\section{KAYNAKLAR}

1. Mirchia K, Richardson TE: Beyond IDHMutation: Emerging Molecular Diagnostic and Prognostic Features in Adult Diffuse Gliomas. Cancers (Basels) 12: 1817, 2020

2. Surveillance, Epidemiology, and End Results: Cancer Stat Facts: Brain and Other Nervous System Cancer https://seer.cancer.gov/statfacts/html/brain.html. 2019

3. Tamimi AF, Juweid M, de Vleeschouwer S ( editors): Epidemiology and OUtcome of Glioblastoma. In: Glioblastoma [ Internet] Brisbane (AU): Codon Publications, Chapter 8, 2017

4. Jovčevska I. Genetic secrets of long-term glioblastoma survivors. Bosn J Basic Med Sci. $2019 ; 19: 116-24$

5. Ostrom QT, Fahmideh MA, Cote DJ, Muskens IS, Schraw JM, Scheurer ME, Bondy ML: Risk factors for childhood and adult primary brain tumors. Neuro Oncol 2019;21: 1357-75 kromozomlarında kısmi kopya kazanımları ortaya koydu. 7 ve 8 'ci kromozomlarda tam kromozom kazanımı görülmesine karşın 10 ve 22'ci kromozomların monosomik olduğu anlaşı1ld.

\section{Sonuc}

GBM'in moleküler patogenez ve biyolojisinin anlaşılmasında önemli gelişmeler kaydedilmesine karşın bunun klinik yansımaları ve dolayısıyla hastalığın küratif anlamda tedavisini sağlayacak yöntemler henüz rutin uygulamaya konulamamıştır. Tamamen yeni tedavi seçeneklerinin geliştirilmesinin yanısıra bunların değerlendirebileceği klinik çalışmaların da yapılması gerekmektedir. Araştırmaların yoğunlaşacağı alanlar kan-beyin bariyerinin aşılması sorunu, moleküler görüntüleme, kan ve BOS'da moleküler işaretleyicilerin daha geniş anlamda kullanılması, moleküler işaretleyicilerin klinik çalışmalara uyarlanması ve daha etkin klinik çalışma modellerinin geliştirilmesi üzerine olacağı ve bunlardan elde edilecek olumlu sonuçlarla GBM patolojisine tam bir tedavi modalitesinin geliştirileceği düşünülmektedir.

6. Schniederjan M, Brat D: Astrocytic neoplasms. Biopsy interpretation of the central nervous system, Lippincott Williams \& Wilkins, 2011;5268 .

7. Komori T: The 2016 WHO Classification of Tumours of the Central Nervous System: The Major points of Revision. Neurol Med Chir ( Tokyo) 2017;57: 301-11,

8. Molenaar RJ, Maciejewski JP, Wilmink JW, van Noorden CJF: Wild type and mutated IDH $1 / 2$ enzymes and therapy responses. Oncogene 2018;37: 1949-60

9. Hu LS, Eschbacher JM, Dueck AC, Heiserman JE, Liu S, Karis JP : Correlations between perfusion MR imaging cerebral blood volume, microvessel quantification, and clinical outcome using stereotactic analysis in recurrent high-grade glioma. Am euroradiol 2012;33: 69-76

10. Wesseling $\mathrm{P}$, van der Laak JA, de Leeuw $\mathrm{H}$, Ruiter DJ, Burger PC: Quantitative immunohistological analysis of the microvasculature in untreated human glioblastoma 
multiforme. Computer-assisted image analysis of whole-tumor sections. J Neurosurg 1994;81: $902-$ 9

11. Suh $\mathrm{CH}$, Kim HS, Jung SC, Park JE, Choi CG, Kim SJ: MRI as a diagnostic biomarker for differentiating primary central nervous system lymphoma from glioblastoma: a systemic review and meta-analysis. J Magn Reson Imaging 2019;50: 560-72,

12. Oz G, Alger JR, Barker PB, Bartha R, Bizzi A, Boesch C, et al. MRS Consensus Group : Clinical proton MR spectroscopy in central nervous system disorders. Radiology 2014;270: 658-79,

13. Gharzeddine K, Hatzoglou V, Holodny AI, Young RJ: MR perfusion and MR spectroscopy of brain neoplasms. Radiol Clin North Am 2019;57:117788 ,

14. Albert NL, Weller M, Suchorska B, Galldiks N, Sofietti R, Kim MM, et al. : Response Assessment in Neuro-Oncology working group and European Association for Neuro-Oncology recommendations for the clinical use of PET imaging in gliomas. Neuro Oncol 2016;18: 11991208

15. Adamson C, Kanu OO, Mehta AI, Di C, Lin N, Mattox AK, Bigner DD: Glioblastoma multiforme: a review of where we have been and where we are. Exp Opin Invest Drug 2009;18:8, 1061-83

16. Wen PY, Weller M, Lee EQ, Alexander BM, Barnholtz-Sloan JS, Barthel FP, et al.: Glioblastoma in adults. society for NeuroOncology (SNO) and European Society of NeuroOncology (EANO) consensus review on current management and future directions. NeuroOncology 2020;22: 1073-13,

17. Roha W, Brasher PM, Bauman G, Anthes M, Bruera E, Chan A, et al. : Abbreviated course of radiation therapy in older patients with glioblastoma multiforme: a prospective randomized clinical trial. J Clin Oncol 2004;22: 1583-88

18. Stupp R, Mason WP, van den Bent MJ and European Organisation for Research and Treatment of Cancer Brain Tumor and Radiotherapy Groups; National Cancer Institute of Canadian Clinical Trials Group. Radiotherapy plus concomitant and adjuvant temozolomide for glioblastoma. $N$ Eng J Med 2005;352: 987- 96

19. Hegi ME, Diserense A-C, Gloria T, Hamou M-F, de Tribolet N, Weller $\mathrm{M}$, et al. : MGMT gene silencing and benefit from temozolomide in glioblastoma. N Eng J med 2005;352: 997-03,

20. Draaisma K, Chatzipli A, Taphoorn M, Kerkhof M, Weyerbrock A, Sanson M, et al. : Molecular evolution of IDH wild-type glioblastoma treated with standard of care affects survival and design of precision medicine trials: a report from Erotic 1542 study. J Clin Oncol 2020;38:81- 99,

21. Krex D, Klink B, Hartman C, von Deimling A, Pietsch T, Simon $M$,et al. : Long-term survival with glioblastoma multiforme. Brain 2007;130 : 2596-2606

22. Liu L, Bäcklund M, Nilsson BR, Grandén D, Ichimura K, Goika HM, Collins VP: Clinical significance of EGFR amplification and the aberrant EGFRvIII transcript in conventionally treated astrocytic gliomas. $J \mathrm{Mol}$ Med ( Berl) 2005;83: 917-26

23. Hegi ME, Stupp R: withholding temozolomide in glioblastoma patients with unmethylated MGMT promoter- still a dilemma. Neuro Oncol 2015;17: 1425-27,

24. Gargini R, Segura-Collar B, Herránz B, GarciaEscudero V, Romero-Bravo A, Nūńez FJ, et al.: The IDH-TAU-EGFR triad defines the neovascular landscape of diffuse gliomas. $S c i$ Transl Med 12 (527) ex 1501, 2020

25. Wu X, Sooman L, Lennartsson J, Bergström S, Bergqvist M, Gullbo J, Ekman S: Microtubule inhibition causes epidermal growth factor receptor inactivation in oesophageal cancer cells. Int $J$ Oncol 2013;42: 297-304, 